\title{
Economic Integration and Unemployment in Mercosur
}

\author{
Luis Rene Caceres
}

Unicef

\begin{abstract}
This paper quantifies the interdependence in labor markets that exists in the Mercosur countries. Two sets of panel data are constructed: one formed by the aggregation of annual time series data from Argentina and Brazil, and another with data from Uruguay and Paraguay. These two sets of data are used to estimate a Var model that includes the following variables: economic growth, real effective exchange rates, and unemployment rates. Another Var is estimated including the change in the wage levels in place of the unemployment rates. The results indicate that strong cross border effects ensue between countries such that national unemployment rates drop in response to shocks of economic growth and devaluation in other member countries. The paper ends with a series of recommendations on the design of regional stabilization policies.
\end{abstract}

- JEL Classification:F15, F42

- Keywords: Economic integration, unemployment, policy coordination.

\section{Introduction}

Recent research on economic integration in Latin America has emphasized themes of regional policy coordination (Escaith and Paunovic, 2003), meeting the conditions for the establishment of an optimal currency area (Caceres, 2000, Allegret and Sand-Zantman, 2009), the adoption of a common currency (Caceres, 2009a; Alesina and Barro, 2000; Karras, 2002, Corbo, 2001, Hallwood et al., 2006), and the role of institutions in the integration process (Caceres, 2008a, $2009 \mathrm{~b})$. The study of the impact of economic integration on labor markets has

*Corresponding address: Social Policy Specialist, Unicef, 5802 Nicholson Lane no. 801, Rockville, MD, 22852, USA, Telephone: 202-415-7056, E-mail: luisrenecaceres@ yahoo.com.

C 2011-Center for Economic Integration, Sejong Institution, Sejong University, All Rights Reserved. 
focused on the effects on wages, ${ }^{1}$ while its repercussions on unemployment has received relatively little attention, despite the prominent place that integration has traditionally occupied on the agenda of national policies, and the prevalence of persistent unemployment and underemployment in many countries. This could be a reflection of the assumption that labor markets are not readily responsive to regional policies, given the supposedly strict regulations that govern national labor markets.

The dearth of analytical studies on economic integration and employment is noted in the European Union as well, where recent studies have dwelt on the effects resulting from the adoption of common labor standards. ${ }^{2}$ The European Employment Strategy promulgated recommendations in 1997 to national authorities on the generation of more and better jobs and on strengthening social cohesion. ${ }^{3}$ This strategy has been part of the Lisbon Strategy, which was adopted in 2000 and was reformulated in 2005. Reference should be made as well to the important analysis of unemployment in some of the EU countries which have emphasized the roles of external economic shocks, national institutions, and restrictive monetary policy. ${ }^{4}$

There is a literature formulated around Okun's Law that has presented evidence of the close association between economic growth and unemployment. ${ }^{5}$ Moreover, the quantification of the cross border growth effects between member countries of an integration program has been quantified in several studies. ${ }^{6}$ Thus, it can be postulated that inasmuch as economic integration gives rise to the transmission of cross border growth impacts, these growth impulses will lead to a reduction of national unemployment beyond what would be obtained in the absence of the economic integration program. Taking that into consideration, as well the evidence existing in the case of Latin American countries of a close relationship between unemployment and poverty (Caceres, 2008b; Gasparni and Gutierrez, 2007), it can be expected that economic integration would have effects on poverty reduction. Thus, the topic of interest is to what degree does economic integration enables

\footnotetext{
${ }^{1}$ See, Esquivel and Rodriguez (2003); Hanson (2003, 2005), Vos et al. (2006).

${ }^{2}$ See Dehejia and Samy (2008).

${ }^{3}$ On the European Employment Strategy and the Lisbon Strategy see, Raveaud (2007), Bongardt and Torres (2007), and Deroose et al. (2008). See Nickell and Layard (1998), Blanchard and Wolfers (2000), Schettkat and Sun (2009).

${ }^{4}$ See Nickell and Layard (1998), Blanchard and Wolfers (2000), Schettkat and Sun (2009).

${ }^{5}$ On Okun's Law see Blackley (1991), Moosa (1997), Knotek (2007). On the theoretical underpinning of Okun's law see Prachowny (1993).

${ }^{6}$ See, among others, McKibbin and Sachs (1991).
} 
domestic variables in a given country to reduce the unemployment rate of its integration partners.

Mercosur has had a successful integration experience, with rising levels of trade that reached $\$ 25,775$ million in $2006 .^{7}$ That year, the main exporting countries were Brazil, with $\$ 13,950$ million, followed by Argentina with $\$ 9,949$ million, Uruguay $\$ 956.8$ million, and Paraguay $\$ 917$ million (see Table 1). Mercosur has been the object of many studies, particularly on the common external tariff (Olerreaga and Soloaga, 1999), transport costs (Amjadi and Winters, 1997), regional policy coordination (Rodriguez Prada, 1997), dynamic and static effects of integration (Bekerman and Sirlin, 2001), the nature of the business cycle, (Allegret and Sand-Zantman, 2007), convergence dynamics, (Blyde, 2006), the role of the exchange rate regime (Allegret and Sand-Zantman, 2008) and direct foreign investment (Chudnovsky, 2007), among others. These studies have highlighted the important potential that resides in Mercosur to propel the member countries' development. In effect, this paper shows that important benefits exist to a given Mercosur country since its unemployment rate decreases in response to shocks to economic growth and devaluation in other member countries. It is shown, as well, that the adoption of a common currency can be an important trade, growth and employment creating mechanism by virtue of its role in uniformly stimulating employment, and thus attenuating stagnation tendencies.

\section{Methodology}

In this paper a Var model is estimated using panel data for two groups of countries: one consisting of the aggregation of time series data of Brazil and Argentina, the largest and more industrialized economies, and another one resulting from the aggregation of times series data for Uruguay and Paraguay, the smaller

Table 1. Mercosur Exports, 2006 (Millions USD).

\begin{tabular}{lccccc}
\hline Exports from: & \multicolumn{5}{c}{ Exports to: } \\
\hline & Argentina & Brazil & Paraguay & Uruguay & Total \\
\hline Argentina & & 8131.7 & 621.3 & 1196.3 & 9949.3 \\
Brazil & 11713.8 & & 1230.5 & 1006.1 & $13,950.4$ \\
Paraguay & 168.5 & 327.9 & & 420.2 & 916.6 \\
Uruguay & 281.3 & 618.2 & 59.1 & & 958.6 \\
\hline
\end{tabular}

${ }^{7}$ The source of trade data is IMF, Direction of Trade, several issues. 
countries. The panel series were constructed using annual national data for the 19912008 period for each country, thus yielding series of 36 points for each panel. ${ }^{8}$

The variables included in the Vars are the economic growth rates, CreciBrAr, CreciUrPar; unemployment rates, DesempBrAr, DesempUrPar; the indexes of the real effective exchange rate, ReerBrAr, ReerUrPar; and the index of real wages, RemuBrAr, RemuUrpar. ${ }^{9}$ All variables were tested for the existence of unit roots and it was found that the economic growth rates were integrated of order zero, while the exchange rates, unemployment rates and wages had unit roots, and thus entered the Var as first differences. In order to orthogonalise the residuals a recursive ordering was employed whereby the variables that enter later in the ordering impact those that enter earlier only with lags. The assumption is that variables listed later are considered to be more endogenous. The assumption is that variables listed later in the ordering impact those listed earlier only with lags and thus variables listed earlier are considered to be more exogenous. The variables considered to be least endogenous was CreciBrAr and CreciUrPar, in that order, followed by the exchange rate variables $D($ Reerr $A r)$ and $D($ ReerUrPar), and the most endogenous variables were considered to be the unemployment rates, D(DesempBrAr, D(DesempUrPar). The underlying assumption is that Brazil-Argentina variables are less endogenous than those of Uruguay-Paraguay, given their larger size.

The order of the variables is (CreciBrAr, CreciUrPar, D(ReerBrAr), D(ReerUrPar), $D($ DesempBrAr), D(DesempUrPar $)$ ), where the letter $\mathrm{D}$ denotes the first difference of the respective variable. Another Var was estimated using the changes in the indexes of real wages in place of the unemployment variables, so as to detect their responses to economic growth and to the real exchange rate. All Vars were estimated with two years lags in all variables.

\section{Impulse response Functions}

The graphs presented on the following pages show the responses of the unemployment rates, accumulated for a period of ten years, to one standard deviation shocks to the following variables:

\section{A. Economic Growth}

Graph 1 shows the trajectory of the change in BrAr's unemployment rate to one

${ }^{8}$ The source of data is ECLAC (2008).

${ }^{9}$ The letters $\mathrm{BrAr}$ and $\mathrm{UrPar}$ denote, respectively, the aggregation of annual time series data for Brazil and Argentina, and Uruguay and Paraguay. 
Graph 1. Accumulated Response of D (DESEMPBRAR) to Cholesky One S.D. Innovations

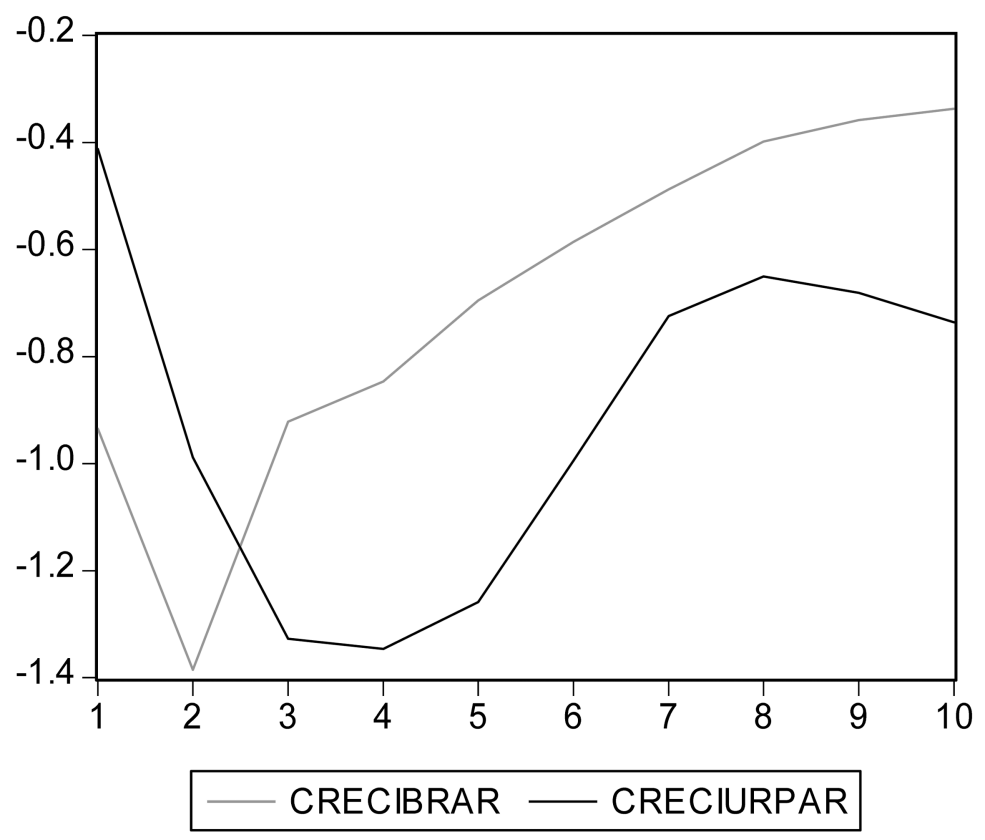

standard deviation shocks to economic growth in $\mathrm{BrAr}$ and in $\mathrm{UrPar}$. It can be seen that in the first case the initial response consists of a drastic drop, which reaches the lowest point after two years and starts to increase thereafter, showing a negative accumulated value at the end of the period. The response to economic growth in UrPar is negative as well, and of the same magnitude as the response to its own economic growth, but reaches its lowest point after four years. It should be noted that after three years the accumulated response of BrAr's unemployment rate to economic growth in UrPar is more accentuated than its response to its own economic growth.

Graph 2 shows the response of a change in UrPar's unemployment rate to economic growth in both groups of countries. Initially UrPar's unemployment rate falls in response to BrAr's economic growth and starts to increase after two years. The response to UrPar's economic growth is negative and shows the lowest value after three years, a value lower than the response to BrAr's growth. Note that at the end of the period the accumulated value of the response of UrPar's unemployment rate to $B r A r$ 's economic growth denotes a larger reduction in unemployment than the response to its own economic growth. This shows that a given Mercosur 
Graph 2. Accumulated Response of D (DESEMPURPAR) to Cholesky One S.D. Innovations

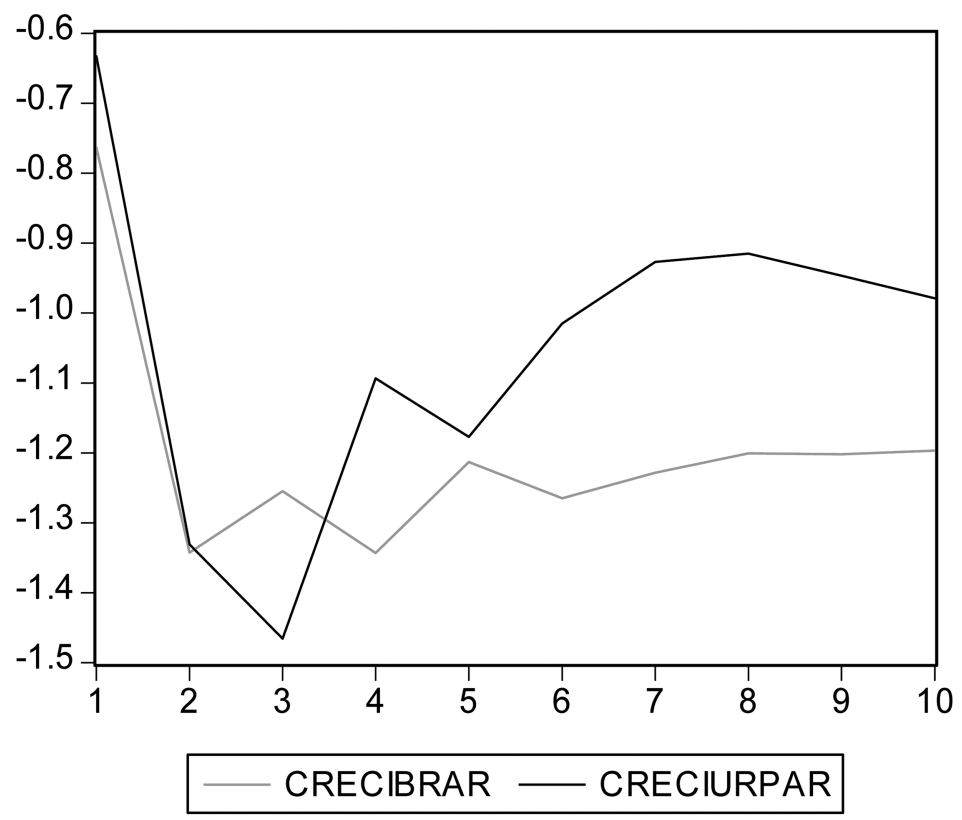

member country could offset the potential increases in its unemployment rate resulting from its own economic stagnation, if the other countries were experiencing rapid growth. As well, the results above indicate that in an integrating area Okun's law should be reformulated taking into account domestic and spillover effects.

\section{B. Devaluation}

The response of BrAr's unemployment rate to a shock to UrPar's real effective exchange rate shows initially a small increase in the unemployment rate, which may be explained by the "protection" obtained by UrPar by virtue of the depreciation of its currency, that enables it to sell more to, or import less, from $B r A r$. But this effect disappears after two years when the response of the unemployment rate becomes negative and remains so until the end of the period. This may reflect the dynamism gained by UrPar economy following its devaluation, resulting in that after two years it demands more imports from $B r A r$. The response of BrAr's unemployment rate to its own devaluation takes the form of a drastic drop that reaches the lowest value after three years. At the end of the period this accumulated response is still negative and larger than the response to 
Graph 3. Accumulated Response of D(DESEMPBRAR) to Cholesky One S.D. Innovations

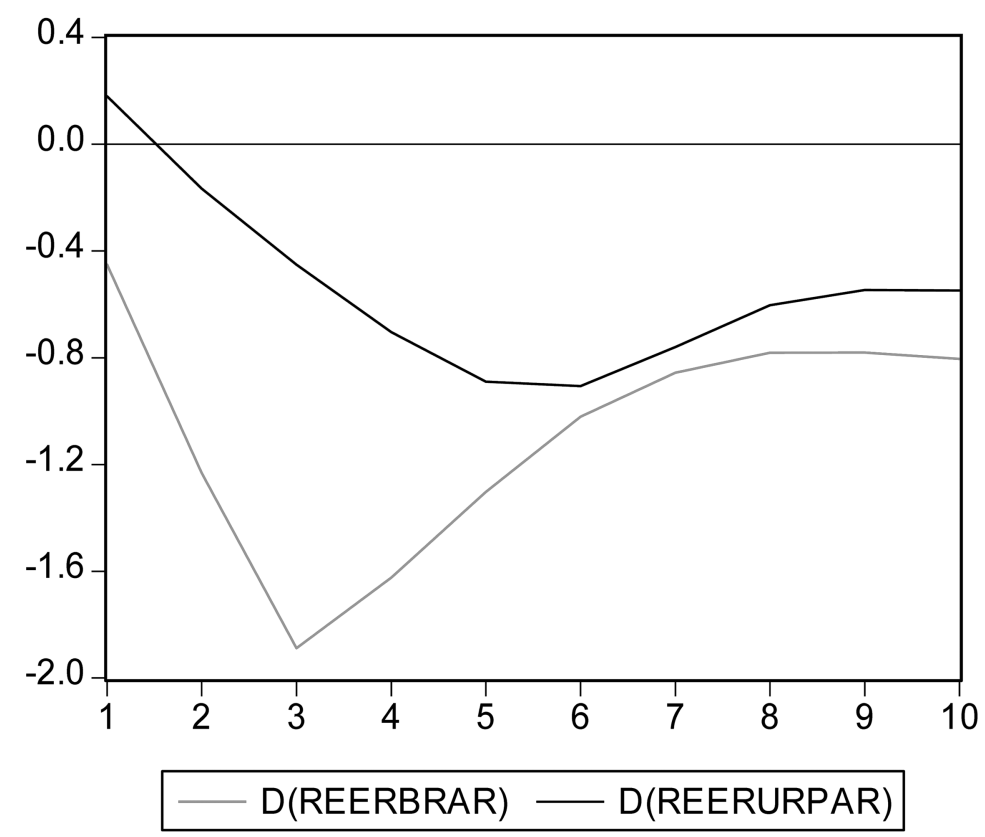

the devaluation in UrPar. Comparing Graphs 1 and 3 it can be noted that BrAr's devaluation leads to deeper reduction in unemployment than the shock to economic growth. This highlights the importance of devaluation as a tool to stimulate employment. It should be mentioned that several studies have found evidence for developed countries that the devaluations of their currencies have led to increases in employment (Burgess and Knetter, 1998; Kandil and Mirzaie, 2003; Goldberg and Tracy, 2000), while similar evidence for a sample of Latin American countries has been presented by Frenkel and Ros (2006). ${ }^{10}$

The responses of UrPar's unemployment rate to a shock to its own and BrAr's exchange rates are shown on Graph 4. It can be seen that, as in the previous case, the unemployment rate increases initially in response to depreciation in $B r A R$, but thereafter falls rapidly and reaches its lowest value after four years. The response of the unemployment rate to a shock to UrPar's real exchange rate is more pronounced than the response to $B r A R$ 's depreciation. These cases illustrate the importance of the real exchange rate in reducing unemployment in an economic integration program.

${ }^{10}$ Review of the literature on the responses of employment to devaluation can be found in Ngandu (2009). See also Ros (2005). 
Graph 4. Accumulated Response of D(DESEMPURPAR) to Cholesky One S.D. Innovations

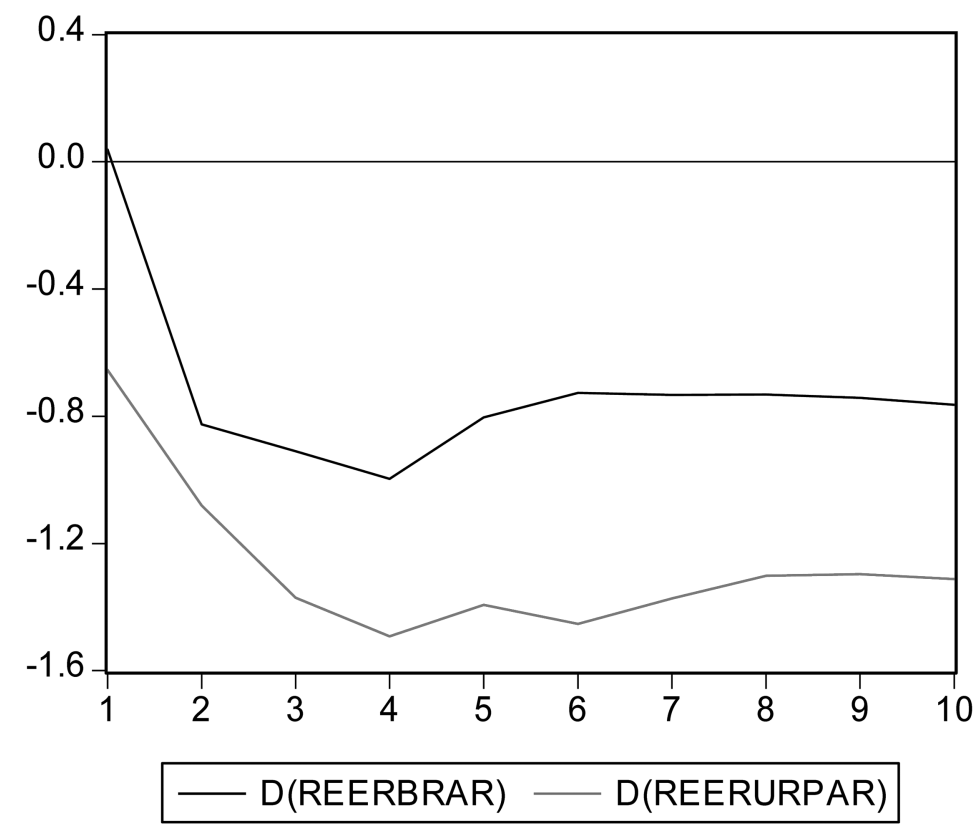

\section{Variance Decomposition Matrix}

Table 2 presents the variance decomposition matrix of the variables included in the Var. ${ }^{11}$ The elements of this matrix provides information on the relative importance of each variable in determining its own variance and the variance of the others, while the impulse response functions indicate that direction of change of one variable in response to a variation in another.

It can be seen that the variance of CreciBrAr is determined mainly by the change in its real effective exchange rate, which exerts a component of 33.5032, and by the change in its unemployment rate (7.6604). Similarly, the variance of UrPar's economic growth is influenced by its real exchange rate (10.7575), and by the change in BrAr's unemployment rate (10.5284). The latter effect is larger than the effect received from its own unemployment rate (2.1498). Note that the autonomous component of BrAr's economic growth (43.7837) is smaller than that of UrPar (67.3493), which is explained by its susceptibility to its real exchange rate.

The variance of the change in BrAr's exchange rate is influenced by its own

${ }^{11}$ The elements of this matrix, as well as those of the matrix shown on Table 3, correspond to a period of five years. 
Table 2. Variance Decomposition Matrix

\begin{tabular}{|c|c|c|c|c|}
\hline \multirow{2}{*}{ Effects received by: } & \multicolumn{4}{|c|}{ Effects exerted by: } \\
\hline & CreciAR & CreciUrPar & $D(\operatorname{ReerBrAr})$ & $D($ ReerUrPar $)$ \\
\hline CreciBrAr & 43.7837 & 6.3660 & 33.5032 & 2.0599 \\
\hline CreciUrPar & 6.8566 & 67.3493 & 2.3585 & 10.5284 \\
\hline$D(\operatorname{ReerBrAr})$ & 13.7415 & 8.6564 & 67.0091 & 3.6429 \\
\hline$D($ ReerUrPar $)$ & 2.9961 & 39.5787 & 4.7975 & 42.1882 \\
\hline$D(U n B r A r)$ & 20.0473 & 9.4877 & 21.4967 & 42.1882 \\
\hline \multirow[t]{2}{*}{$D$ (Usurpar) } & 17.9838 & 19.8810 & 15.1324 & 13.5977 \\
\hline & $D(U n B r A r)$ & $D($ Usurpar $)$ & & \\
\hline CreciBrAR & 7.6604 & 6.6269 & & \\
\hline CreciUrPar & 10.5284 & 2.1498 & & \\
\hline$D(\operatorname{ReerBrAr})$ & 1.5803 & 5.3698 & & \\
\hline$D$ (ReerUrpar) & 1.4963 & 1.9482 & & \\
\hline$D(U n B r A r)$ & 36.8812 & 7.0710 & & \\
\hline$D$ (Usurpar) & 6.5344 & 26.8706 & & \\
\hline
\end{tabular}

economic growth (13.7415), followed by UrPar's economic growth (8.6564). Similarly, the variance of UrPar's exchange rate is determined mainly by its economic growth (39.5787). It seems that on a national basis, economic growth and the real exchange rate exert reciprocal influences, and that the variances of exchange rates are not influenced by unemployment rates.

For its part, $B r A r$ 's unemployment rate is affected by its economic growth (20.0473), and by its real exchange rate (21.4967). Note that the sum of these two effects are larger than the autonomous component (36.8812). Similar results are shown by the variance of UrPar's unemployment rate, whose largest component is received from its economic growth (19.8810) and from BrAr's economic growth (17.9838), and the effects received from the change in the real effective exchange rate are appreciable. These results indicate that there are strong effects from growth to unemployment but the reciprocal effects from unemployment to growth are smaller.

\section{Effects of Real Wages}

Another Var was estimated including the changes in the indexes of real wages in place of the unemployment rates. Graph 5 shows the response of the change in real wages in $B r A r$ to shocks to the economic growth rates. BrAr's wages show a large increase in response to its own economic growth, which keeps increasing at the end of the period. The initial response to UrPar's economic growth is lower but 
Graph 5. Accumulated Response of D(REMUBRAR) to Cholesky One S.D. Innovations

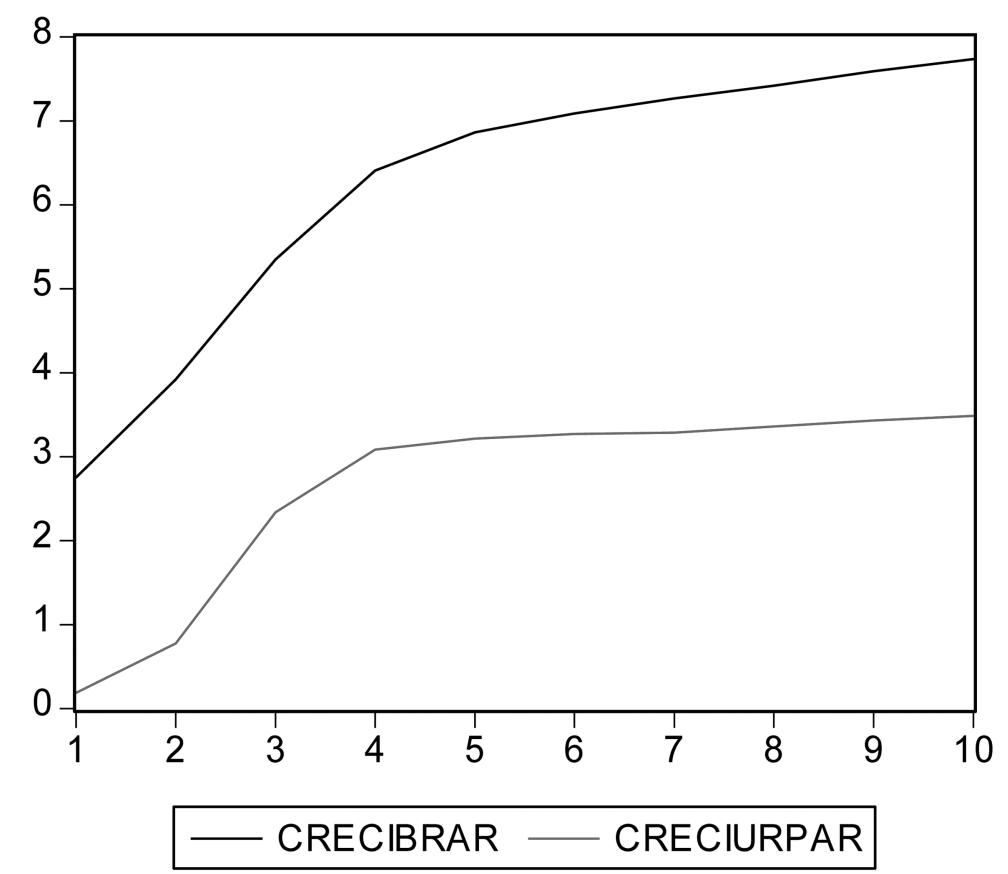

Graph 6. Accumulated Response of D(REMUURPAR) to Cholesky One S.D. Innovations

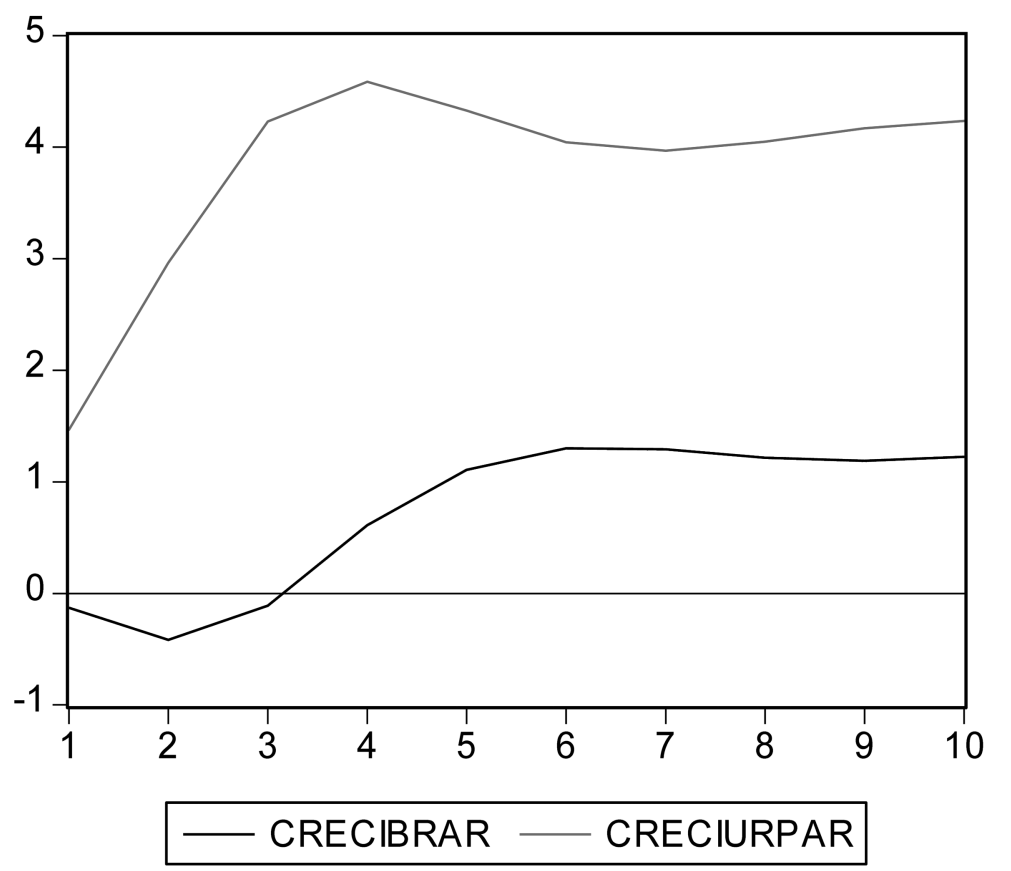


Graph 7. Accumulated Response of D(REMUBRAR) to Cholesky One S.D. Innovations

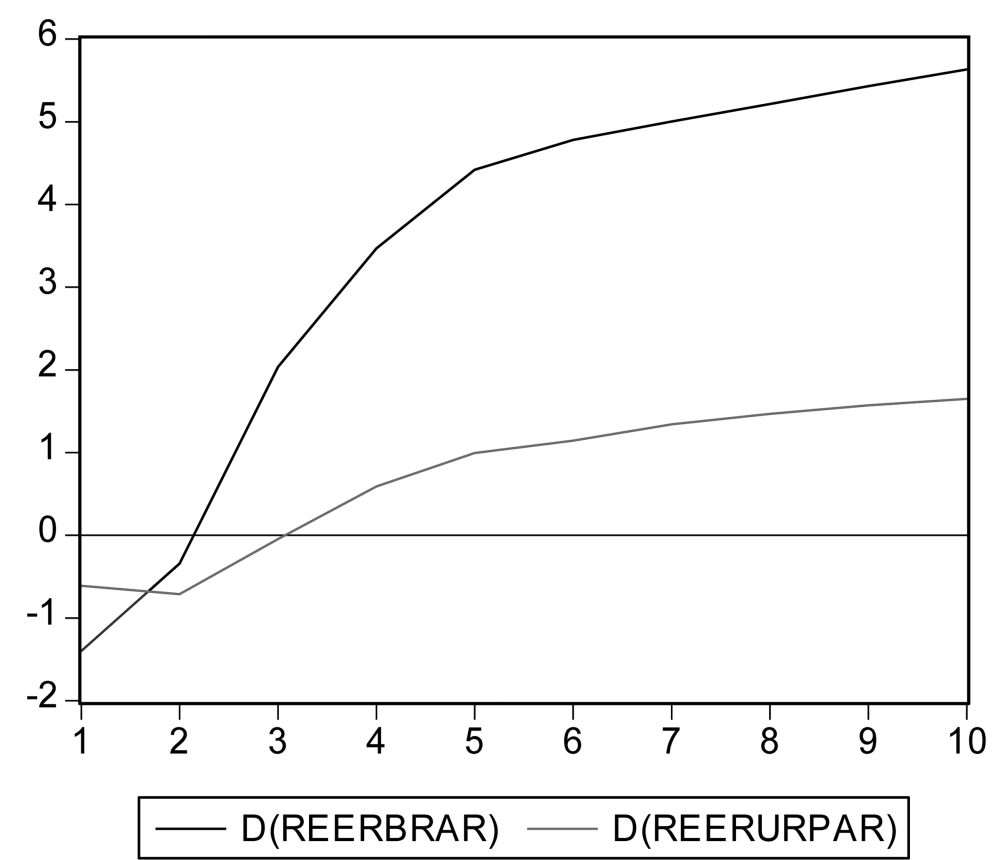

continues to grow and reaches a steady value after four years, with a value half the size of the response to growth in $B r A R$.

The initial response of UrPar's change in its index of real wages to its economic growth is large, (Graph 6), and continues to increase to reach a steady value after four years. It should be noted that UrPar's wages response to BrAr's economic growth is negative in the first three years but becomes positive through the rest of the period.

It can be seen in Graph 7 that the initial response of BrAr's wage index to a shock to its exchange rate is negative, but becomes positive after two years, and continues to increase during the rest of period. This negative initial response may be due to the inflationary effect of devaluation that reduces the real wage index. The response to a change in UrPar's exchange rate is similar but smaller in magnitude. In this case the negative response at the beginning of the period may be due to the drop in exports from BrAr destined to UrPar, as a consequence of UrPar's devaluation.

The responses of UrPar's wages to devaluations in BrAr and Urpar show similar paths (Graph 8). The response is positive throughout the period when 
Graph 8. Accumulated Response of D(REMUURPAR) to Cholesky One S.D. Innovations

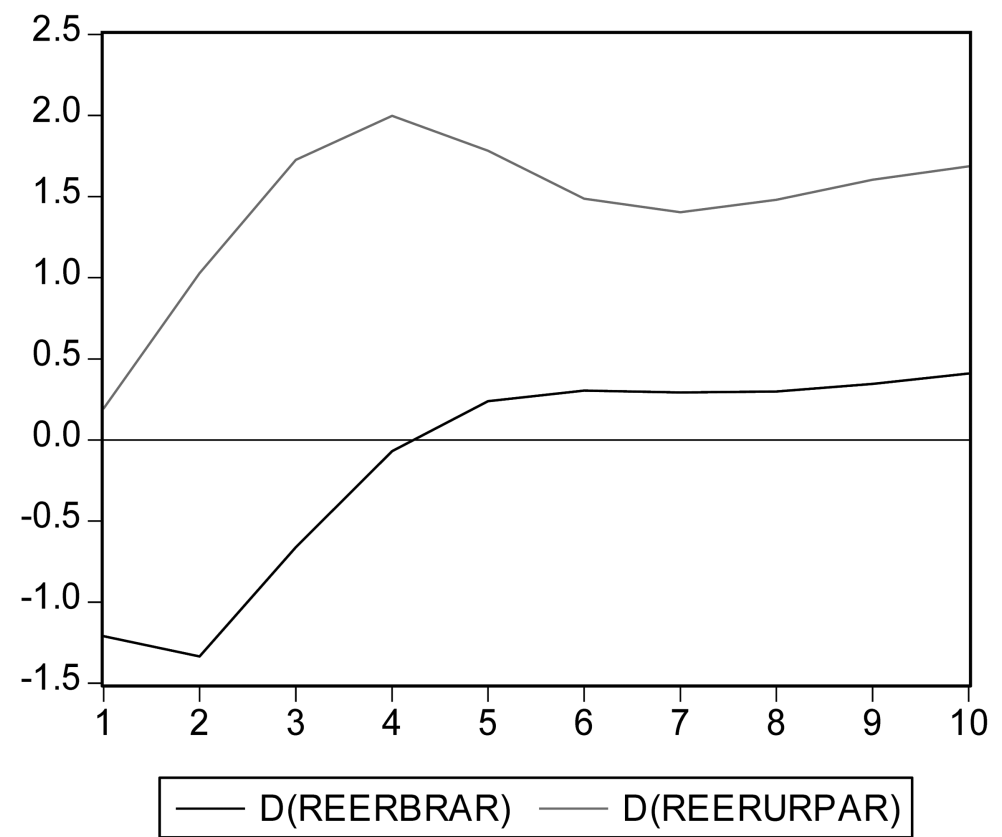

UrPar devalues; however the response to BrAr's devaluation is negative for the first four years, which may be explained by the competitive advantage gained by $B r A r$ 's exports to UrPar resulting from BrAR's devaluation.

The responses of BrAr's wages to economic growth are of the same magnitude as its responses to devaluation, while UrPar's wages' responses to economic growth are larger than the responses to devaluation. These results show that real wage growth is not impaired by devaluations. It should be indicated that evidence exists that labor market response to crisis takes the form of reduction in wages, with countries with large devaluations experimenting large drops in real wages (Fallon and Lucas, 2002). This does not have to be the case for Mercosur, given the experience found in Central America that the integration program acts to increase member countries' national aggregate supplies, by virtue of the regional trade flows, thus mitigating the domestic inflationary pressures (Caceres, 1978). Moreover, this aggregate supply effect resulting from economic integration would dampen domestic inflationary pressures that may occur from devaluation in a given country. An implication is that economic integration exerts a trade creating wealth effect throughout the integrating area, stimulating aggregate demand and thus increasing trade flows. 
Graph 9. Real Effective Exchange Rates in Mercosur Countries

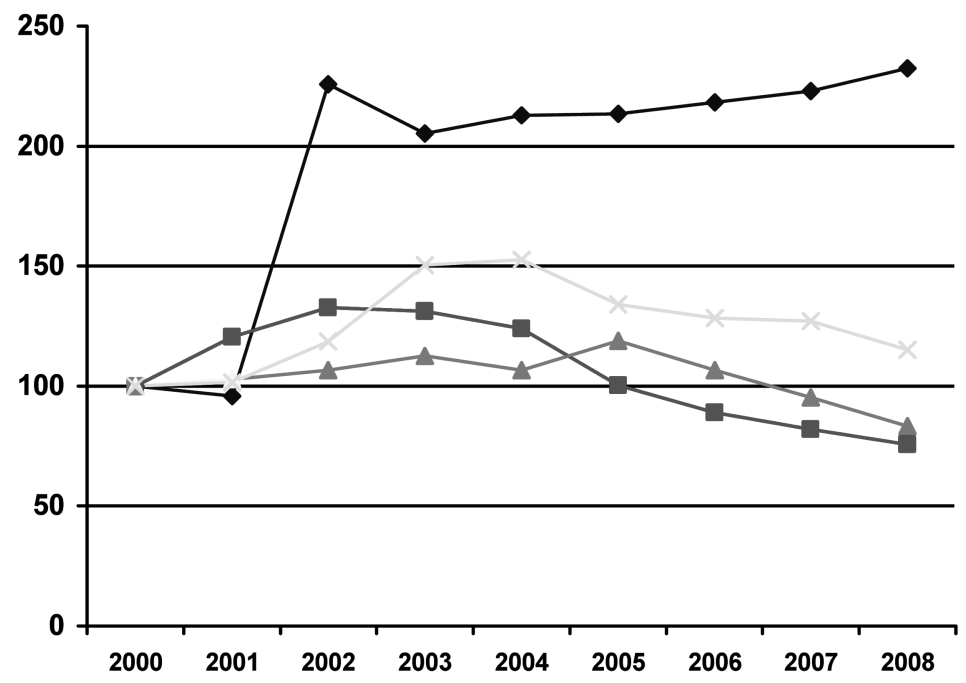

Several studies have indicated that deeper integration among Mercosur countries would be enhanced by the adoption of a common currency (Eichengreen, 1998); the point to be emphasized is that, as was seen on paragraphs above, devaluation has an important role in decreasing unemployment and thus a common currency would provide such stimulus uniformly to all countries, multiplying and augmenting the national stimuli, thus avoiding conflicting responses from countries whose currencies are being appreciated, which may offset the impulses from those whose currencies are depreciating. Graph 9 shows the paths of the effective real exchange rates for the Mercosur countries for the 2000-2008 period. It can be seen that while Argentina was experiencing devaluations, the other countries were on a contrary direction showing appreciation tendencies. It is possible that the stimulus received by Argentina from its devaluation was annulled by the appreciations in the other countries. This would not occur if the countries had a single currency.

\section{Variance Decomposition Analysis Including The Indexes of Real Wages}

The variance decomposition matrix corresponding to the previous variables is shown on Table 3. It can be seen that the effects exerted by BrAr's and UrPar's wages on the variance of $B r A r$ 's economic growth are lower than the effects 
exerted by the unemployment rates shown on Table 2. However, the effects exerted by wages on UrPar's economic growth are larger than those received from the unemployment rates and from its own devaluation. The autonomous components of economic growth for both pairs of countries are larger than in the previous case. The main effect received by $B r A R$ 's economic growth is from its devaluation (33.8566), as was the case in the previous one. However, in UrPar's economic growth the main effect originates in the increase in wages in $\operatorname{BrAr}(13.1819)$, followed by its own increase in wages (10.6186). This can be interpreted as the result of the increase in aggregate output, as consequence from the augmented purchasing capacity in $\mathrm{BrAr}$ and $\mathrm{UrPar}$ by virtue of the increases in wages. Note that the effects of wages on economic growth are larger than the effects from unemployment rates.

As in the previous case shown on Table 2, the main effects on BrAR and UrPar devaluations come from their economic growth (15.8850 and 26.9542 respectively). UrPar's devaluation also receives large effects from its own and $B r A r$ 's wage rises (6.8090) and (4.2211) respectively. Wages in $B r A r$ are affected almost to the same extent by its own economic growth (23.3877) and its own devaluation, (22.1486), a pattern also shown by UrPar's variance of real wages, which receives a component of 28.6931 from its growth rate and of 11.5458 from $B r A r$ 's wages, similar to the effect received from $B r A r$ 's devaluation (11.0207). Note that the autonomous component of the variance of wages in $B r A r$ (40.7269),

Table 3. Variance decomposition matrix

\begin{tabular}{|c|c|c|c|c|}
\hline \multirow{2}{*}{ Effects received by: } & \multicolumn{4}{|c|}{ Effects exerted by: } \\
\hline & CreciAR & CreciUrPar & $D(\operatorname{ReerBrAr})$ & $D($ ReerUrPar $)$ \\
\hline CreciBrAr & 45.6353 & 10.5016 & 33.8566 & 4.1735 \\
\hline CreciUrPar & 7.3089 & 58.0044 & 4.2239 & 6.6622 \\
\hline$D(\operatorname{ReerBrAr})$ & 15.8850 & 6.1436 & 58.6745 & 8.1848 \\
\hline$D($ ReerUrPar $)$ & 3.6610 & 26.9542 & 6.9518 & 34.7028 \\
\hline$D($ RemuBrAr $)$ & 23.377 & 6.4409 & 22.1486 & 2.6402 \\
\hline \multirow[t]{2}{*}{$D($ RemuUrpar $)$} & 4.4556 & 28.6931 & 11.0207 & 6.2264 \\
\hline & $D(\operatorname{RemuBrAr})$ & $D($ RemUrPar $)$ & & \\
\hline CreciBrAR & 4.9826 & 0.8503 & & \\
\hline CreciUrPar & 13.1819 & 10.6186 & & \\
\hline$D(\operatorname{ReerBrAr})$ & 4.2211 & 6.8090 & & \\
\hline$D$ (ReerUrpar) & 17.7660 & 9.9642 & & \\
\hline$D($ RemuBrAr $)$ & 40.7269 & 4.6558 & & \\
\hline$D$ (RemuUrpar) & 11.5458 & 38.0582 & & \\
\hline
\end{tabular}


and UrPar (38.0582), are relatively small, denoting a high degree of flexibility in their adjustment.

\section{Labor Market Flexibility}

The results presented above may be interpreted as evidence that the labor markets in these countries are flexible, given that unemployment and wages respond rapidly to changes in economic growth and in the real effective exchange rate. However, it has to be indicated that a large percentage of the labor market is constituted by the informal sector. The evidence for some Latin American countries shows that approximately three out of four new jobs are created in the informal sector, which provides an idea of its large dimension. An estimation of its size realized by ECLAC (2008) puts its dimension at $44.9 \%$ of the regional economy in 2008. It has been estimated that in Brazil the size of the informal sector in the domestic economy is in the range of 40 to 63\% (Henley, Arabsheibami and Carneiro, 2009). Moreover, the unemployment rates in the countries comprised in this work are very low, with average values around $8 \%$, which would denote the presence of underemployment. An analysis of the labor market in El Salvador (Caceres and Amaya, 2008) indicated that employment in the formal sector starts to increase only after economic growth has surpassed the threshold of $6 \%$, and that a rise in the rate of underemployment in a given year is followed by a steep rise in the unemployment rate two years later, which evidences the precariousness of employment in the informal sector. Thus, the results presented in this work may reflect the flexibility prevailing in the informal sector.

Reference should be made to Blackley (1991) who found, for the case of the States of the US, that the drops in the unemployment rates in response to economic growth are more pronounced in those States with higher percentages of manufacturing output and high personal income taxes, and that the responses were lower in States with large percentages of young and of female workers. These results may be viewed as contrary to those obtained in this study, given the relatively high proportions of women and young workers expected to prevail in Mercosur countries' labor forces.

Another explanation for the apparent labor market flexibility may reside in a recent study by Cunningham (2009), who analyzed the labor market performance of young workers in Brazil, Argentina and Mexico and found that young workers tend to change jobs very often, so as to "shop around" and seek to discover the line 
of occupation where they would like to settle in, which gives rise to both relatively high labor mobility and unemployment rates. This high degree of market "churning" may be an explanation for the rapid response of unemployment to economic growth found in this paper. Reference should also be made to the study by Bosch and Maloney (2007) who found in several Latin American countries that employment in the informal sector is of short duration. As well, a study for Colombia Anderson Schaffner (2001) found that employment is very unstable, such that the probability of a person remaining at her or his job during the first year of tenure is only 0.18 , versus 0.31 in the US. However, both probabilities increase through time and reach the same magnitude after four years.

\section{Concluding Remarks}

The results above provide evidence of the inherent capacity of economic integration in lowering member countries' unemployment rates, which makes the integration process an effective instrument to stabilize employment on a regional scale. In this way, economic integration can be an instrument to mitigate the effects from international recessions and to prevent domestic recessionary tendencies from acquiring force. ${ }^{12}$ This indicates the importance of giving high priority to maintaining the dynamism of intraregional trade flows in times of crisis, be it by favorable terms of credit lines, agile payments mechanisms, etc.

As well, an important mechanism to protect employment resides in the capacity of infrastructure investments to generate employment, particularly in the labor intensive areas such as tertiary road construction and road maintenance, as has been shown recently for the case of Latin America by Schwartz, Andrea and Dragoiu $^{13}$ (2009). Mercosur countries can structure regional infrastructure investment programs whose financing could be supported by the creation of a subregional or regional fund whose resources would be tapped in times of economic downturns, thus emulating the European Union's structural funds that have been found to exert stabilization effects on member countries' economies. ${ }^{14}$ These

\footnotetext{
${ }^{12}$ On the case of Central America see Caceres (2009a).

${ }^{13}$ These authors estimate that $\$ 1$ billion program of "typical" Latin American country infrastructure projects of tertiary roads and road maintenance which give rise to the generation of around 300,000 500,000 jobs.

${ }^{14}$ On the stabilization role of the Structural Funds see Asdrubali and Kim (2008). It should be mentioned that the countries members of the East African Community have proposed imposing a tax on their custom revenues to finance the administrative expenses of their regional organizations (Braude, 2008).
} 
resources would be available to those countries that were experiencing economic downturns, so as to protect employment levels, which as has been shown above, would lead to stimulating employment in the other member countries. ECLAC's (2009) recent inventory of counter cyclical policies that the Latin American countries are undertaking to counteract the effects of the global crisis can be the starting point to move towards the coordination of a Mercosur-wide response to crisis. The point that should be emphasized is that unemployment is a source of serious social ills, and their amelioration through appropriate employment stabilization policies would have significant social benefits.

In the medium term the most effective stabilization policies that the Mercosur countries can follow consist of implementing programs that would impart resiliency to the national economies, so that they grow faster and are able to withstand adverse repercussions from the global economy. These programs would be structured around the main objective of substantially increasing the levels of human capital. It has been shown that the main source of economic instability of the Latin American economies is their relative low levels of education and health, which do not generate adequate stocks of human capital to sustain a dynamic growth path (Kaminsky and Pereira, 1996). It has been shown, as well, that in the Latin American countries increasing human development levels lead to more dynamic economic growth and to improvements in governance (Caceres, 2010). Given their low levels of human capital the economies have to resort to physical capital, which is expensive and relies on foreign borrowing, which may result in higher vulnerability. ${ }^{15}$

The employment creating effects of economic integration, and particularly of a common currency, have not received sufficient attention in the economics literature. The criteria prevailing in current literature for the adoption of a common currency rests of the degree of synchronism among the economic variables of the member countries, signifying that if the synchronism is high the countries can adopt a single currency and forgo the conduction of their own monetary policies. However, the adoption of a common currency would promote employment in all countries and thus would contribute to enhance and strengthen area-wide economic synchronism by virtue of the demand effects resulting from rising or stable employment levels. Thus economic synchronism is endogenous to monetary union.

\footnotetext{
${ }^{15}$ It should be indicated that a study of the sources of growth in the Latin American economies (Baffes and Shah, 198) showed that the contributions from human capital are much larger than those of physical capital.
} 
Hence it is convenient that Mercosur countries devise a timetable conducive to the adoption of a common currency. It should be stressed that the benefits resulting from protecting employment levels are possible in an economic integration scheme, but they are unattainable in a framework of unilateral trade opening.

These results indicate the convenience of moving away from the traditional approach to economic integration, which is based on trade creation and diversion effects associated with tariff reductions, and formulate a framework whereby integration is a means to combat poverty and unemployment. In that way, countries member of an integration program should adopt an area wide employment generation and poverty reduction policy, so as to exact all the important benefits residing in the integration program.

By making poverty the ultimate focus of economic policy in the context of economic integration, much can be gain in terms of employment and poverty reduction.

Received 22 February 2010, Revised 15 January 2011, Accepted 24 January 2011

\section{References}

Alesina, Alberto, \& Barro, R. (2001), Dollarization, American Economic Review, 91(3), 381-385.

Allegret, Jean Pierre \& Sand-Zantman, A. (2007), Distangling Business Cycles and Macroeconomic Policy in Mercosur: A VAR and Unobserved Components Approaches, Journal of Economic Integration, 22(3), 482-514.

Allegret, Jean-Pierre \& Sand-Zantman, A. (2009), Does a Monetary Union Protect Against External Shocks? An Assessment of Latin American Integration, Journal of Policy Modeling, 31, 102-118.

Allegret, Jean Pierre \& Sand-Zantman, A. (2008), Modeling the Impact of Real and Financial Shocks on Mercosur: The Role of the Exchange Rate Regime, Open Economies Review.

Amjadi, Azita, \& Winters, A. (1997), Transport Costs and Natural Integration in Mercosur". World Bank Policy Research Working Paper WPS 1742.

Anderson Schaffner, J. (2001), Job Stability in Developing and Developed Countries: Evidence from Colombia and the United States, Economic Development and Cultural Change, 511-535.

Asdrubali, PierFederico \& Kim, S. (2008), The Economic Effects of the EU Budget: A VAR Analysis, Journal of Common Market Studies, 46(5), 933-968.

Baffes, John \& Shah, A. (1998), Productivity of Public Spending, Sectoral Allocation Choices and Economic Growth, Economic Development and Cultural Change, 46(2). 
Bekerman, Marta \& Sirlin, P. (2001), Impactos Estaticos y Dinamicos del Mercosur, Revista de la CEPAL. 75, 227-243.

Blackley, Paul R. (1991), The Measurement and Determination of Okun's Law: Evidence from State Economies, Journal of Macroeconomics, 13(4), 573-553.

Blanchard O., \& Wolfers, J. (2000), The Role of Shocks and Institutions in the Rise of European Unemployment", The Economic Journal, 110, 1-33.

Bongardt, A. \& Torres, F. (2007), Institutions, Governance and Economic Growth in the EU: Is There a Role for the Lisbon Strategy?, Intereconomics, Review of European Ecomic Policy, 42(1), 32-42.

Bosch, Mariano \& Maloney, W. (2007), Comparative Analysis of Labor Market Dynamics Using Markov Process: An Application to Informality, World Bank, Policy Research Working Paper No. 4429.

Braude, Wolfe, (2008), Regional Integration in Africa. Lessons from the East African Community, South African Institute of International Affairs, Johannesburg.

Burges, S. \& Knetter, M. (1998), An International Comparison of Employment Adjustment to Exchange Rate Fluctuations, Review of International Economics, 6(1), 151-164.

Blyde, Juan S. (2006), Convergente Dynamics in Mercosur, Journal of Economic Integration, 21(4), 784-815.

Caceres, Luis R. (2010), Governance, Human Capital and Economic Growth in Latin America, Revistade lInstituto Interamericanode Derechos Humanos, 51.

Caceres, Luis R. (2000), Integración Monetaria en las Regiones Centroamericana y Andina, Comercio Exterior, 50(7), 552-565.

Caceres, Luis R. (2009a), Integración Economica, Capital Humano y Crisis en Centroamérica, unpublished.

Caceres, Luis R. (2009b), Capital Humano, Instituciones y Crecimiento Economico en Centroamérica, Comercio Exterior.

Caceres, Luis R. (2008a), Instituciones e Integración Economica en Centroamérica, Comercio Exterior.

Caceres, Luis R. (2008b), El Derecho al Trabajo y Mercados Laborales en America Latina, Estudios Centroamericanos.

Caceres, Luis R. \& Amaya, P. (2008), Subempleo y Pobreza en El Salvador, unpublished.

Caceres, Luis R. (1978), Integración Económica e Inflación en Centroamérica. Un Modelo Espacial, El Trimestre Económico, 45, 811-839.

Chudnovsky, Daniel (2007), Inversion Extranjera Directa y Desarrollo: La Experiencia del Mercosur, Revista de la Cepal, 92, 7-23.

Corbo, Vitorio (2001), Is It Time for a Common Currency for the Americas?, Journal of Policy Modeling, 23, 241-248.

Cunningham, Wendy. (2009), Unpacking Youth Unemployment in Latin America, World Bank Policy Research Working Paper No. 5022.

Dehejia, Vivek H. \& Yiagadeesen, S. (2008), Labor Standards ad Economic Integration in the European Union: An Empirical Analysis, Journal of Economic Integration, 23(4), 817847. 
Deroose, Servaas, Hodson D., \& Joost Kuhlmann, J. (2008), The Broad Economic Policy Guidelines: Before and alter the Re-Launch of the Lisbon Strategy, Journal of Common Market Studies, 46(4), 827-848.

ECLAC. (2009), La Reaccion de los Gobiernos de America Latina y el Caribe Frente a la Crisis Internacional: Una Presentacion Sintetica de las Medidas de Politica Anunciadas hasta el 20 de Febrero de 2009, Santiago de Chile.

ECLAC. (2008), Social Panorama of Latin America 2008, Santiago de Chile.

Eichengreen, Barry (1998), Does Mercosur Need a Single Currency?, NBER Working Paper No. 6821.

Escaith, Hubert \& Paunovic, I. (2003), Regional Integration in Latin America and Dynamic Gains from Macroeconomic Cooperation, ECLAC, Santiago de Chile.

Esquivel, G. \& Rodriguez, J. (2003), Technology, Trade and Wage Inequality in Mexico Before and After Nafta, Journal of Development Economics, 72, 543-563.

Fallon, Peter R. \& Lucas, R. E. B. (2002), The Impact of Crisis on Labor Markets, Households Incomes, and Poverty: A Review of Evidence, World Bank Research Observer, 17(1), 21-45.

Frenkel, R., \& Ros J. (2006), Unemployment and the Real Exchange Rate in Latin America, World Development, 34(4), 631-646.

Gasparini, Leonardo \& Gutierrez F. (2007). Growth and Income Poverty in Latin America and the Caribbean: Evidence from Household Surveys, Review of Income and Wealth, 53(2), 209-245.

Goldberg, L. \& J. Tracy J. (2000), Exchange Rates and Local Labor Markets, in The Impact of International Trade on Wages, (Ed.) Feenstra, R. C., University of Chicago Press, Chicago.

Halwood, P. Marsh, I., \& Scheibe, J. (2006), An Assessment of the Case for Monetary Union or Official Dollarization in Five Latin American Countries, Emerging Markets Review, 7(1), 52-66.

Hanson, Gordon H. (2003), What Has Happened to Wages in Mexico Since Nafta?, NBER Working Paper No. 9563.

Hanson, Gordon H. (2005), Globalization, Labor Income and Poverty in Mexico, NBER Woking Paper no. 11027.

Henley, Andrew, Arabsheibami, G. R. \& Carneiro, F. G. (2009), On Defining and Measuring the Informal Sector: Evidence from Brazil, World Development, 37(5), 992-1003.

Kandil, M. \& Mirzaie I. (2003), The Effects of Dollar Appreciation on Sectoral Labor Market Adjustments: Theory ad Evidence, The Quarterly Journal of Economics and Finance, 43, 89-117.

Karras, Georgios. (2002), Costs and Benefits of Dollarization: Evidence from North, Central, and South America, Journal of Economic Integration, 17(3), 502-516.

Kaminsky, Graciela L. \& Pereira, A. (1996), The Debt Crisis: Lessons of the 1980's for the 1990's, Journal of Development Economics, 50(1), 1-24.

Knotek II, Edward. (2007), How Useful is Okun's Law?, Federal Review Bank of Kansas 
City Economic Review, pp. 73-103.

Olerreaga, Marcelino \& Soloaga I. (1999), What is Behind Mercosur's Common External Trarrif?, World Bank Policy Research Working Paper No. 2231.

Prachowny, M. F. J. (1993), Okun's Law: Theoretical Foundations and Revised Estimates, The Review of Economics and Statistics, 75(2), 331-336.

McKibbin Warwick J. \& Sachs, J. D. (1991), Global Linkages: Macroeconomic Interdependece and Cooperation in the World Economy, The Brookings Institution, Washington DC.

Moosa, Imad A. (1997), A Cross-Country Comparison of Okun's Coefficient, Journal of Comparative Economics, 24, 335-356.

Nickell, S. \& Layard, R. (1998), Labor Market Institutions and Economic Performance, CEP Discussion Paper No. 407.

Ngandu, Stewart N. C. et al., (2009), The Impact of Exchange Rate Movements on Employment: The Economy-Wide Effect of a Rand Appreciation, Development Southern Africa, 26(1), 111-129.

Raffer, K. (1998), The Tobin Tax: Reviving a Discussion, World Development, 26(3), 529538.

Raveaud, P. (2007), The European Employment Startegy: Towards More and Better Jobs?, Journal of Common Market Studies, 45(2), 411-434.

Rodriguez, Prada, Gonzalo. (1997), Anclas Nominales y Escenarios de Coordinacion Macroeconomica en el Mercosur, Revista de la Cepal, 62.

Ros, J. (2005), El Desempleo en America Latina Desde 1990, Mexico, ECLAC.

Schettkat, Ronald \& Sun, R. (2009), Monetary Policy and European Unemployment, Oxford review of Economic Policy, 25(1), 94-108.

Schwartz, Jordan Z., Andres, L. A. \& Dragoiu, G. (2009), Crisis in Latin America: Infrastructure Investment, Employment and the Expectations of Stimulus, Word Bank Working Paper No. 5009.

Vos, Rob, Ganuza, S., Morley, S., \& Robinson, S. (2006), Eds., Who Gains from Free Trade: Export-Led Growth, Inequality and Poverty in Laton America, London, Routledge Studies in Development Economics.

UNDP (1994), Human Development Report 1994, New York, UNDP.

ul Haq, M., Kaul, I., \& Grunberg, I. (2006), The Tobin Tax, Coping with Financial Volatility, New York, UNDP. 